\title{
Diagnostic measures for assessing numerical forecasts of African Easterly Waves
}

\author{
NiCOLE SANDER ${ }^{* 1,2}$ and SARAH C. JONES ${ }^{1}$ \\ ${ }^{1}$ Institut für Meteorologie und Klimaforschung, Universität Karlsruhe/Forschungszentrum Karlsruhe, Germany \\ 2 current affiliation: Max-Planck-Institut für Meteorologie, Hamburg, Germany
}

(Manuscript received March 18, 2007; in revised form December 24, 2007; accepted January 24, 2008)

\begin{abstract}
The utility of a number of diagnostic measures for assessing forecasts of the synoptic-scale flow over West Africa and the eastern Atlantic is investigated. The forecasts were carried out using the COSMO Model provided by the Deutscher Wetterdienst (DWD) for a three week period in 2004. During this period a number of African Easterly Waves (AEWs) were observed, three of which subsequently developed into the Hurricanes Danielle, Frances and Ivan. A sequence of $72 \mathrm{~h}$ forecasts were initialised twice daily from the DWD global analysis, using analyses and $12 \mathrm{~h}$ forecasts for the boundary conditions. A variety of diagnostics were used to assess the forecasts including objective analyses of jet and trough axes and Hovmoeller plots. The zonal wind was averaged along the objectively analysed jet axes over West Africa and the Atlantic for the forecasts and analyses. This provides a robust measure of the jet strength that takes into account the spatial variability of the jet location and is not tied to either the maximum wind speed or a particular geographic location. Application of this measure to assess the forecasts showed that overall the jet strength was well represented. The largest errors were associated with local jet variations due to misrepresentation of the African Easterly Waves in the forecasts. The objectively analysed trough axes are used to give a visual indication of the forecast quality. Hovmoeller plots proved useful for assessing the evolution of the AEWs, although the interpretation was difficult when convection in the model produced small-scale but strong vorticity anomalies. The results of this study will be applied to future case studies based on the African Monsoon: Multidisciplinary Analysis (AMMA) special observing periods.
\end{abstract}

\begin{abstract}
Zusammenfassung
Um Vorhersagen der synoptischskaligen Strömung über Westafrika und dem Ostatlantik zu bewerten, wurde die Anwendbarkeit verschiedener diagnostischer Methoden untersucht. Für einen dreiwöchigen Zeitraum des Jahres 2004 wurden mit Hilfe des vom Deutschen Wetterdienst (DWD) zur Verfügung gestellten COSMO Modells Simulationen durchgeführt. Während dieser Periode wurden zahlreiche African Easterly Waves (AEWs) beobachtet, von denen sich anschließend drei zu den Hurrikanen Danielle, Frances und Ivan entwickelten. Es wurde eine Abfolge von 72-Stunden-Vorhersagen, deren Randwerte alle 12 Stunden mit Analysen und Vorhersagen des globalen Modells des DWD initialisiert wurden, erstellt. Verschiedene diagnostische Methoden, wie die objektive Analyse der Jet- und Trogachsen sowie Hovmöller-Plots wurden angewandt, um die Vorhersagen zu bewerten. Entlang der so bestimmten Jetachsen über Westafrika und dem Atlantik wurde der Zonalwind sowohl für die Vorhersagen als auch die Analysen gemittelt. Dies liefert ein robustes Maß für die Stärke des Jets, welche die räumliche Variabilität der Lage des Jets miteinbezieht aber weder an die maximale Windgeschwindigkeit, noch an eine bestimmte geographische Region gebunden ist. Bei der Beurteilung der Vorhersagen zeigte die Verwendung dieser Größe eine allgemeine gute Wiedergabe der Stärke des Jets. Die größten Fehler traten in Zusammenhang mit lokalen Variationen des Jets auf, welche aufgrund einer falschen Wiedergabe der African Easterly Waves in den Vorhersagen zu stande kam. Die objektiv analysierten Trogachsen geben die Möglichkeit die Vorhersagequalität visuell zu beurteilen. Hovmöller-Plots sind bei der Bewertung der zeitlichen Entwicklung von AEWs hilfreich. Jedoch war die Interpretation schwierig, wenn aufgrund von Konvektion das Modell kleinskalige aber dennoch starke Vorticity Anomalien verursachte. Die Ergebnisse dieser Studie werden bei zukünftigen Fallstudien, basierend auf den Hauptuntersuchungsperioden von Afrikanischer Monsun: Multidisziplinäre Analysen (AMMA), Verwendung finden.
\end{abstract}

\section{Introduction}

The dominant synoptic-scale weather systems over West Africa are African Easterly Waves (AEWs) (RIEHL, 1954; CARLSON, 1969a, b). Mesoscale convective systems embedded in AEWs are responsible for a significant amount of heavy precipitation over land (e.g.,

${ }^{*}$ Corresponding author: Nicole Sander, Max-Planck-Institut für Meteorologie, Bundesstraße 55, 20146 Hamburg, Germany, e-mail: nicole.sander@zmaw.de
REED et al., 1977; FINK and REINER, 2003). Over the Atlantic, the organised convection embedded in AEWs provides the initial disturbance for the majority of Atlantic tropical cyclones (e.g., LANDSEA et al., 1998). Thus the ability to forecast African Easterly Waves and the mesoscale systems embedded within them is important both for the African countries affected by them directly and in order to be able to predict tropical cyclogenesis. 
African Easterly Waves are disturbances that grow on the African Easterly Jet (AEJ) (BURPEE, 1972; PARKER et al., 2005), whose development is generally attributed to mixed baroclinic and barotropic instability (CHARNEY and STERN, 1962). The strong easterly flow of the AEJ is a typical phenomenon in summertime over Sahelian Africa. It develops in association with diabatically forced meridional circulations due to surface heating over the Sahara and moist convection in the Intertropical convergence zone (THORNCROFT and BLACKBURN, 1999). It is in approximate thermal wind balance with the strong positive meridional temperature gradients (COOK, 1999). Typically the jet axis is located near $15^{\circ} \mathrm{N}$ at 600 to $700 \mathrm{hPa}$. Its maximum mean wind speed is about $12 \mathrm{~m} \mathrm{~s}^{-1}$ (THORNCROFT and BLACKBURN, 1999). Recent studies discuss the role of deep convection in the initiation of AEWs (HSIEH and COOK, 2005; HALL et al., 2006). Preferred tracks for AEW disturbances have been identified to the south of the jet along about $11^{\circ} \mathrm{N}$ and to the north of the jet along about $17^{\circ} \mathrm{N}$ (e.g. REED et al., 1977). The northern waves have their maximum amplitude at $\sim 850 \mathrm{hPa}$ and the southern waves at $\sim 700 \mathrm{hPa}$ (FINK et al., 2004).

There is a growing need for accurate numerical weather forecasts over West Africa in order to provide timely warnings of severe weather. An important step towards improving numerical weather prediction is the ability to assess model output in an objective manner and with respect to features that determine the evolution of the weather systems of interest. The aim of the work described in this paper is to assess the utility of certain diagnostics for such an assessment. To this end we investigate the representation of the synoptic scale flow over West Africa and the eastern Atlantic in an operational limited area numerical weather prediction model - the COSMO Model provided by the Deutscher Wetterdienst (DWD) (DOMS and SCHÄTTLER, 2002). Specifically, we focus on the application of diagnostic techniques to assess the synoptic-scale flow over Africa and the eastern Atlantic. We have carried out a series of $72 \mathrm{~h}$ forecasts initialised twice daily from 12 August to 6 September 2004. During this period there were a number of AEWs, three of which developed into the Hurricanes Danielle, Frances and Ivan.

The main diagnostic tool applied in this investigation is an algorithm to identify the jet and trough axes following a method proposed by BERRY et al. (2007). It is based on a previous study (REED et al., 1977) in which the trough and ridge axes are defined by a sign reversal of the meridional wind. Using this and other diagnostic tools we study the development of AEWs in the period under investigation.

This paper is structured as follows. In section 2 we give a brief description of the model set-up and diagnostic techniques. In section 3 we analyse the AEJ in the analyses and forecasts, and in section 4 the AEWs. In the final section we discuss the implications for modelling the results from the African Monsoon: Multidisciplinary Analysis (AMMA) ${ }^{1}$ Special Observing Periods (SOP).

\section{Model, data and diagnostic techniques}

The COSMO model (DOMS and SCHÄTTLER, 2002) is a non-hydrostatic limited-area atmospheric prediction model. To date it has been used not only for operational numerical weather prediction but also for various scientific applications. The model equations for compressible flow in a moist atmosphere are formulated in rotated geographical coordinates and a generalised terrain following height coordinate. A variety of physical processes are parameterised. Of particular relevance for this study is the representation of convection (TIEDTKE, 1989), sub-grid scale turbulence (MELLOR and YAMADA, 1974), a Kessler-type representation of grid-scale precipitation, and radiation (RITTER and GELEYN, 1992). For this study we use a model domain from $45^{\circ} \mathrm{W}$ to $20^{\circ} \mathrm{E}$ and $0^{\circ} \mathrm{N}$ to $30^{\circ} \mathrm{N}$ with a horizontal resolution of $0.25^{\circ}$ and 35 levels in the vertical. Land use data are available from the DWD at this horizontal resolution. The initial conditions and lateral boundaries are taken from the global (GME) analyses of the DWD that are produced using a multivariate optimum interpolation scheme (MAJEWSKI et al., 2002). For the lateral boundaries, analyses are used at 00 and 12 UTC and values from the first $12 \mathrm{~h}$ of the relevant forecast at hourly intervals in between.

In a recent paper BERRY et al. (2007) describe a method for the objective analysis of the AEJ axis and the AEW trough lines. This is an adaptation of the method of HEwson (1998) that was developed for the objective analysis of midlatitude frontal systems and can be applied to different datasets and coordinate systems. BERRY et al. (2007) base their analysis on the nondivergent streamfunction calculated from the relative vorticity. In our limited area configuration the streamfunction is not uniquely defined so we follow their methodology but use the total wind field instead of the nondivergent wind. This leads to a somewhat noisier picture, but the locations of the trough axes do not change (THORNCROFT, 2005, personal communication). In order to reduce the noise in the analysis, a 7-point running mean is applied to the wind field in both horizontal directions before the analysis is carried out. Furthermore, the threshold of easterly flow used to identify the jet is increased from 8 to $10 \mathrm{~m} \mathrm{~s}^{-1}$.

${ }^{1}$ www.amma-international.org 


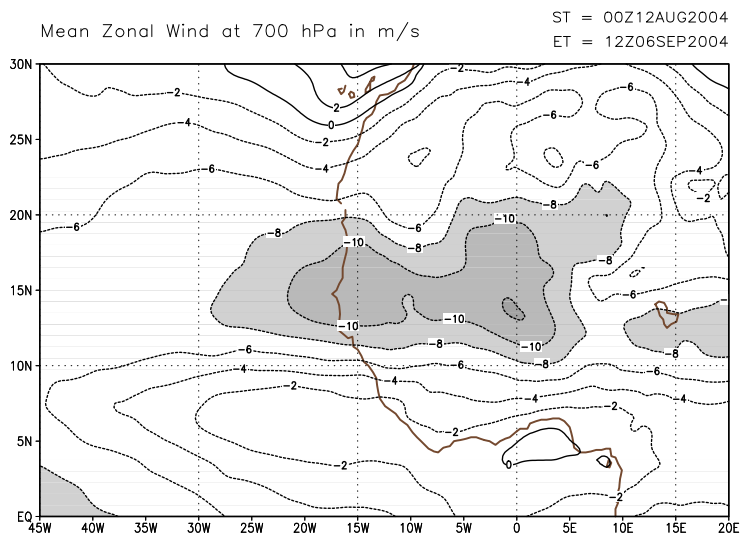

a) Mean zonal wind $700 \mathrm{hPa}$

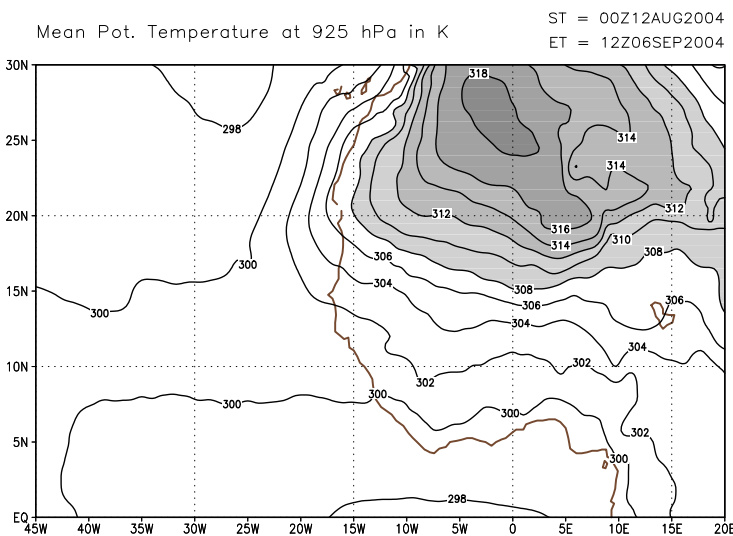

c) Mean potential temperature

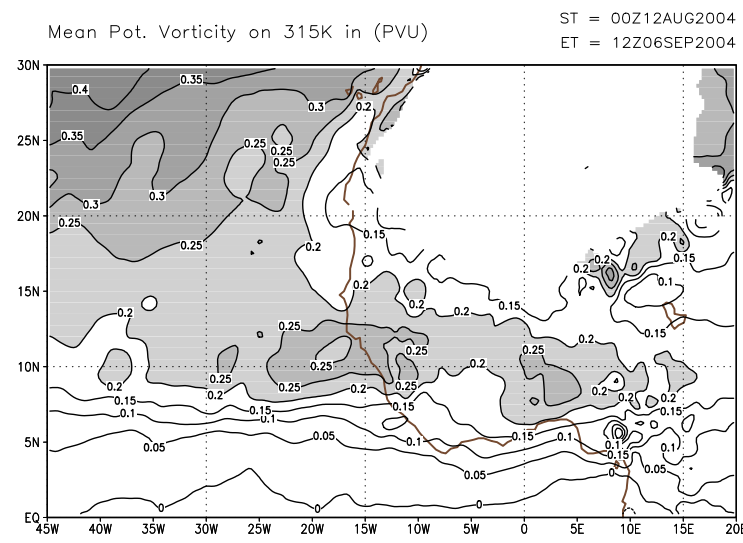

b) Mean potential vorticity

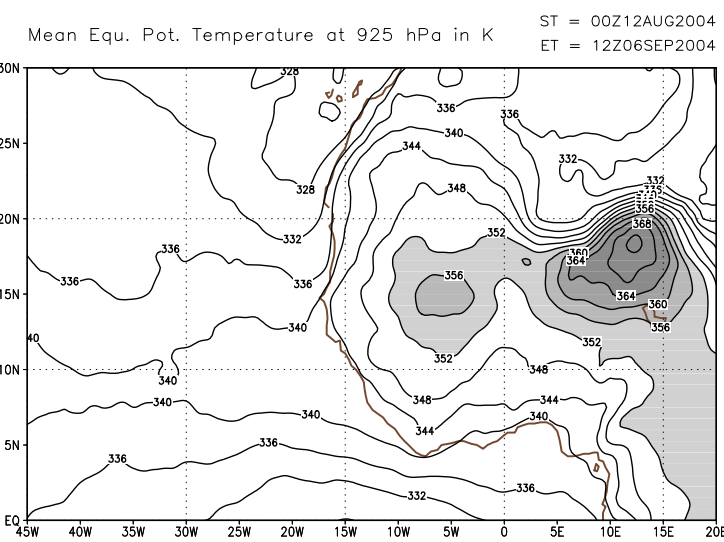

d) Mean eq. pot. temperature

Figure 1: 12 August-06 September 2004 mean fields (averaged using 00 and 12 UTC analysis times). a) Zonal wind at 700 hPa; contoured every $2 \mathrm{~m} \mathrm{~s}^{-1}$, shaded below $-8 \mathrm{~m} \mathrm{~s}^{-1}$. b) Ertel potential vorticity on the $315 \mathrm{~K}$ potential temperature surface; contoured every $0.05 \mathrm{PVU}$ $\left(1 \mathrm{PVU}=1 \times 10^{-6} \mathrm{~K} \mathrm{~kg}^{-1} \mathrm{~m}^{2} \mathrm{~s}^{-1}\right)$, values above $0.2 \mathrm{PVU}$ shaded. c) Potential temperature at $925 \mathrm{hPa}$; contoured every $2 \mathrm{~K}$, values in excess of $308 \mathrm{~K}$ shaded. d) Equivalent potential temperature at $925 \mathrm{hPa}$; contoured every $3 \mathrm{~K}$, values in excess of $352 \mathrm{~K}$ shaded.

\section{Synoptic overview and AEJ}

We begin our analysis with a consideration of the largescale flow i.e. the AEJ. As our focus is on the analysis of $72 \mathrm{~h}$ forecasts, we consider the variability of the AEJ rather than viewing the AEJ as the mean flow over a longer time period. During the period from 12 August to 6 September 2004 the analysed AEJ is clearly defined at $700 \mathrm{hPa}$ over the African continent and extending out over the eastern Atlantic. The jet axis extends along $15^{\circ} \mathrm{N}$ with maximum values of $-12 \mathrm{~m} \mathrm{~s}^{-1}$ on the Greenwich meridian (Fig. 1a).

An indication of a split in the jet is seen to the east of the jet maximum with regions of enhanced zonal wind extending northeastwards as well as due eastwards along $12^{\circ} \mathrm{N}$. The jet maximum occurs at the location of strong potential vorticity (PV) gradient on the $315 \mathrm{~K}$ isentropic surface (Fig. 1b). This surface intersects the AEJ at about $700 \mathrm{hPa}$ over West Africa (THORNCROFT and Hoskins, 1994; DiCKINSON and MOLINARI, 2000). A strip of high PV centred on $10^{\circ} \mathrm{N}$ extends westwards from $15^{\circ} \mathrm{E}$ into the Atlantic Ocean. The existence of this strip is associated with a local reversal in the sign of the meridional PV gradient and is consistent with cyclonic horizontal shear to the south of the jet. The $315 \mathrm{~K}$ surface intersects the ground in the regions of highest surface temperature (Fig. 1c). In this average plot no PV values are plotted at a given location if the $315 \mathrm{~K}$ surface intersected the ground at any time during the three week period. Thus the blank area is much larger than in a single plot for a given time, as shown later in this section. The mean positive meridional potential temperature gradient is associated with the observed easterly shear and its maximum is collocated with the mean negative PV gradient above, so that this mean state supports baroclinic and barotropic growth of AEWs. The maximum in mean equivalent potential temperature at $925 \mathrm{hPa}$ (Fig. 1d) is shifted southwards from the maximum potential temperature indicating the combined influence on $\theta_{e}$ of the hot dry Saharan air and the warm moist air further south. This is in reasonable agreement with previous results of BERRY and THORNCROFT (2005), who analysed a period between 16 July and 15 August 2000. The main difference is the signif- 


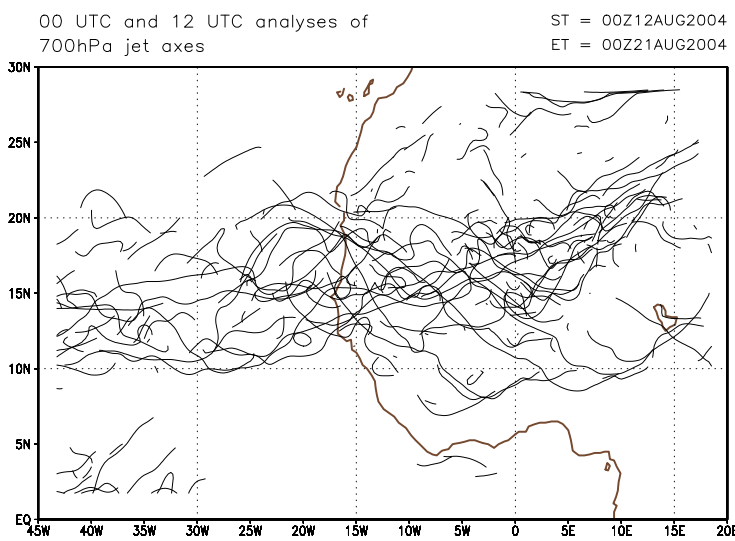

a)12 August-21 August

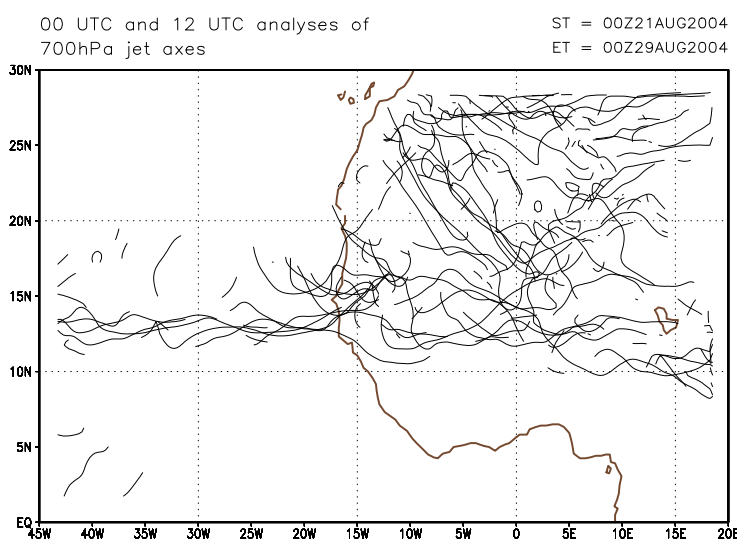

b) 21 August-29 August

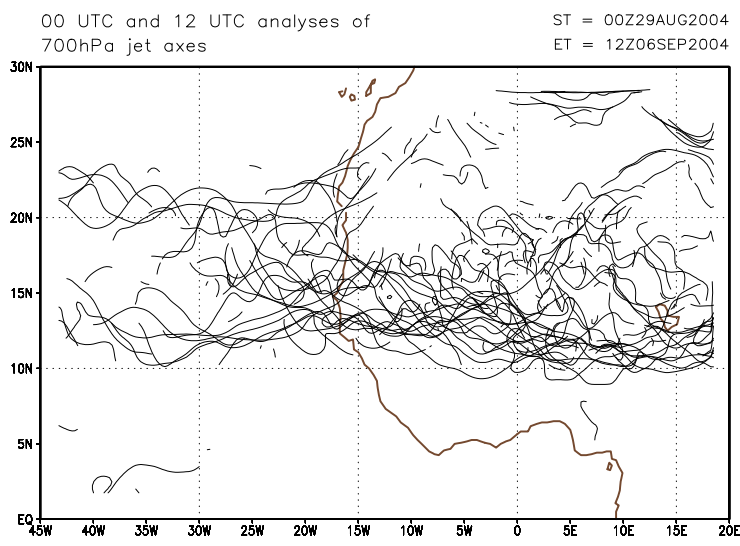

c) 29 August-6 September

Figure 2: Jet axes analysed at $700 \mathrm{hPa}$. a) 12-21 August 2004, b) 21-29 August 2004 and c) 29 August-6 September 2004.

icantly higher maximum of $\theta_{e}$ at about $8^{\circ} \mathrm{E}$. The average jet structure resembles that for GATE Phase II also (FINK et al. 2004).

The variability of the AEJ is explored by considering the location of the jet axis at $700 \mathrm{hPa}$ as calculated objectively twice daily from the analysis fields. Over the 3 week period the jet tends to be split on the eastern side of the domain, with one branch running approximately east-west between $10^{\circ} \mathrm{N}$ and $15^{\circ} \mathrm{N}$ and the other having a northeast-southwest orientation. This is especially noticeable during the first 9 days (Fig. 2a) with the northeast-southwest orientation to the east of $0^{\circ}$ longitude being very pronounced. Further west the jet is found between 10 and $20^{\circ} \mathrm{N}$, both over Africa and over the Atlantic. During the following 8 days (Fig. 2b) there is a very wide spread of the locations where jet axes are identified over Africa, with more axes seen both further south and further north than during the previous period. Over the Atlantic fewer jet axes are identified and these are either in a narrow strip around $13^{\circ} \mathrm{N}$, or are at $15^{\circ} \mathrm{N}$ but do not extend far from the coast. During the final period (Fig. 2c) the jet axes over Africa are now markedly further south, and over the Atlantic a split jet is apparent.

One possible application of the objective jet axes is to assess the representation of the AEJ strength in a model. The variablity in the location of the jet shown in Fig. 2 indicates that averaging over a fixed domain or along a fixed latitude will not give a good indication of the actual jet strength. Here we average the jet strength along the objectively analysed jet axes. The jet axis is defined as the location at which the shear vorticity is zero (BERRY et al., 2007). However, this location will typically not be at a given grid point so we need to average the zonal wind over a certain number of grid points around the jet axis. We achieve this by choosing a threshold value of the shear vorticity, in this case $0.5 \times 10^{-5} \mathrm{~s}^{-1}$, and averaging the zonal wind over all grid points at which the amplitude of the shear vorticity does not exceed this threshhold and for which the easterly flow is stronger than $10 \mathrm{~m} \mathrm{~s}^{-1}$. With the threshold chosen, the averaging is carried out over the grid points directly adjacent to the jet axis in regions where the jet profile is sharply peaked and over a broader region where the jet profile itself is broad. Variation of the threshold from $0.2-2 \times 10^{-5} \mathrm{~s}^{-1}$ resulted in a change in the average jet strength of about $0.3 \mathrm{~m} \mathrm{~s}^{-1}$. Reducing the threshold below $0.2 \times 10^{-5} \mathrm{~s}^{-1}$ resulted in no grid point values being included in the average for substantial sections of the jet axis. Thus we have a rather robust measure of the jet strength that depends on the actual jet structure and not on geographic considerations.

The variability in the analysed jet strength can be seen in Fig. 3 (solid black lines). Here the zonal wind speed is averaged along the objectively identified jet axes over Africa (right) and over the Atlantic (left). Over Africa the jet is strongest in the first days of our period with a maximum average value of $-15.6 \mathrm{~m} \mathrm{~s}^{-1}$ then weakens to about $-11.5 \mathrm{~m} \mathrm{~s}^{-1}$ by 19 August. Subsequently the maximum speed stays around $-13 \mathrm{~m} \mathrm{~s}^{-1}$ for the following 2 weeks and then intensifies somewhat in early September. Over the Atlantic the average jet strength oscillates around about $-12 \mathrm{~m} \mathrm{~s}^{-1}$ in August and increases in strength also in early September.

We now apply the jet strength diagnostic to the model forecasts. This is done every $12 \mathrm{~h}$ for each forecast for 


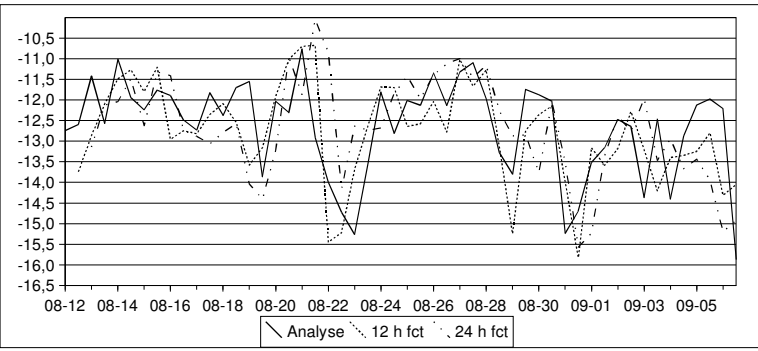

a) Atlantic 12 and $24 \mathrm{~h}$ forecast

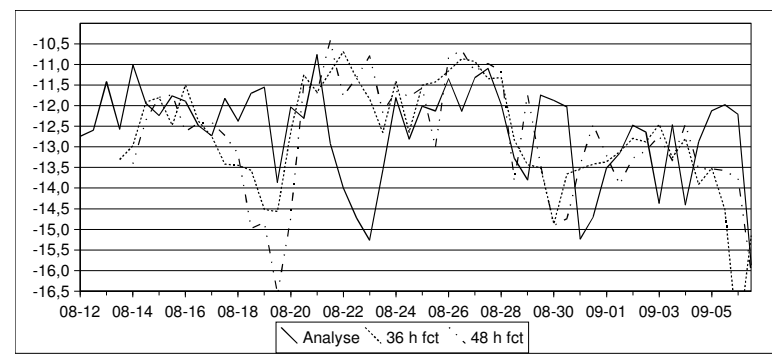

c) Atlantic 36 and $48 \mathrm{~h}$ forecast

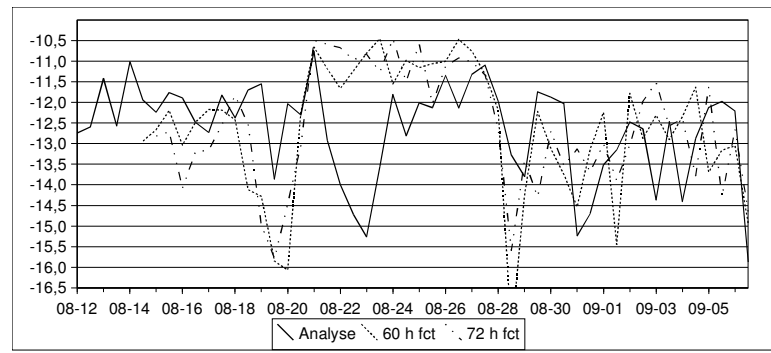

e) Atlantic 60 and $72 \mathrm{~h}$ forecast

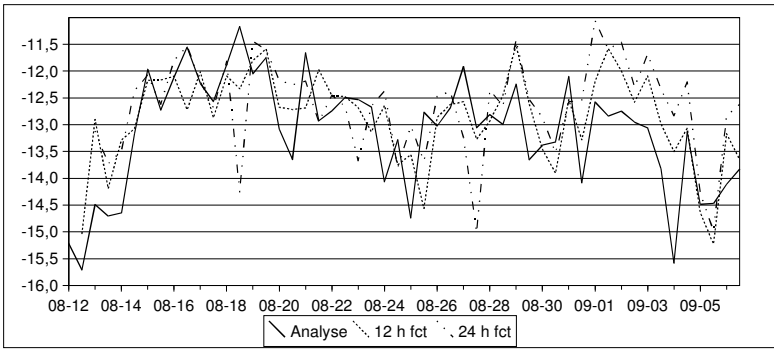

b) Africa 12 and $24 \mathrm{~h}$ forecast

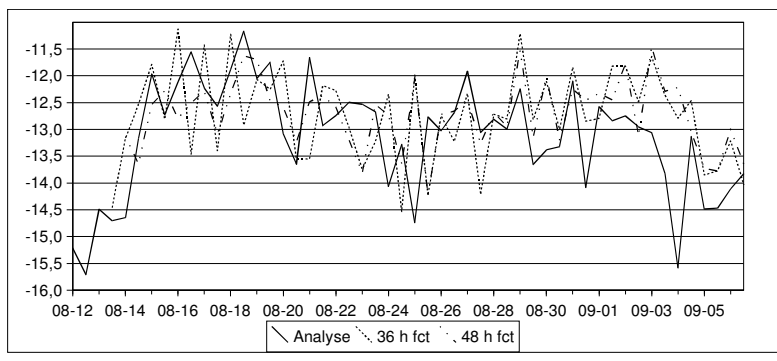

d) Africa 36 and $48 \mathrm{~h}$ forecast

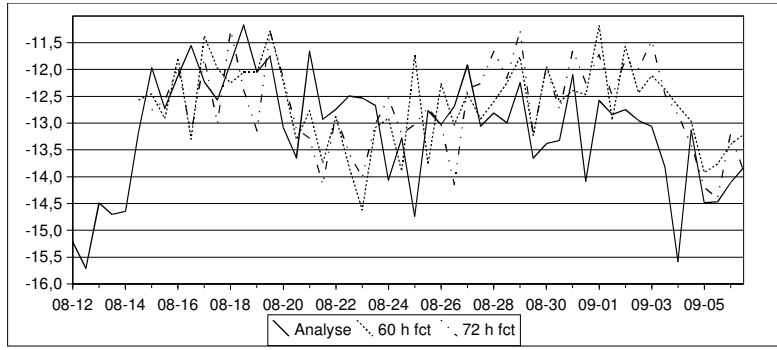

f) Africa 60 and $72 \mathrm{~h}$ forecast

Figure 3: Mean zonal wind in $\mathrm{m} \mathrm{s}^{-1}$ along objectively analysed jet axes (700 hPa) over the Atlantic (left) and Africa (right) between 12 August-6 September 2004 for analysis (solid). a), b) 12 h (dashed) and 24 h (dot-dashed) forecasts. c), d) 36 h (dashed) and 48 h (dot-dashed) forecasts. e), f) $60 \mathrm{~h}$ (dashed) and $72 \mathrm{~h}$ (dot-dashed) forecasts.

the domain over Africa and over the Atlantic. In Fig. 3 the jet strength for a given forecast lead time is plotted for the whole period along with the analysed jet strength. Overall the model forecasts the strength of the AEJ over the Atlantic and Africa quite well even at lead times of $72 \mathrm{~h}$, with an average error of around $1 \mathrm{~m} \mathrm{~s}^{-1}$. This is encouraging, since if there are significant model errors in the large-scale environment, we cannot expect the model to reproduce the synoptic and mesoscale systems.

The jet strength diagnostic identifies two notable exceptions to the overall satisfactory quality of the forecasts. Between 22 and 23 August the jet over the Atlantic intensifies rapidly. This intensification is seen in the 12 and $24 \mathrm{~h}$ forecasts verifying on 23 September 00 UTC, but not in forecasts with longer lead times (Fig. 3c and 3e). On 3 September the jet intensifies over Africa. In this case not even the $12 \mathrm{~h}$ forecast verifying on 4 September 00 UTC reproduces the jet strength well (Fig. 3b).

In order to gain some indication of the origin of these large forecast errors we look at the $315 \mathrm{~K} \mathrm{PV}$ for the analysis and forecasts verifying on 23 August 00 UTC. We see that the rather short jet axis extends from the West African coast at $14^{\circ} \mathrm{N}$ and dips slightly southwards (Fig. 4a). The strong zonal flow along this axis is sandwiched between a region of low PV air between 15 and $20^{\circ} \mathrm{N}$ and a region of high $\mathrm{PV}$ air just south of $10^{\circ} \mathrm{N}$. The low PV air is located directly to the south of an outbreak of Saharan air. The high PV air to the south is associated with the genesis of Hurricane Frances. Neither of these features are well represented in the forecasts with more than $24 \mathrm{~h}$ lead time. The area of low PV air becomes smaller with longer lead time (Fig. 4b, c). The high PV air associated with Hurricane Frances appears well represented in the 12 and $24 \mathrm{~h}$ forecasts, but for longer lead times is either thin, zonally elongated along $10^{\circ} \mathrm{N}$, and bows southwards (Fig. 4b), or remains on the coast near $11^{\circ} \mathrm{N}$ (Fig. 4c). In association with these changes, the flow is more meridionally oriented so that the average zonal wind along the jet axis decreases in the forecast. In later forecasts the jet axis is not identified. Thus the error in the average magnitude of the jet over the Atlantic is 


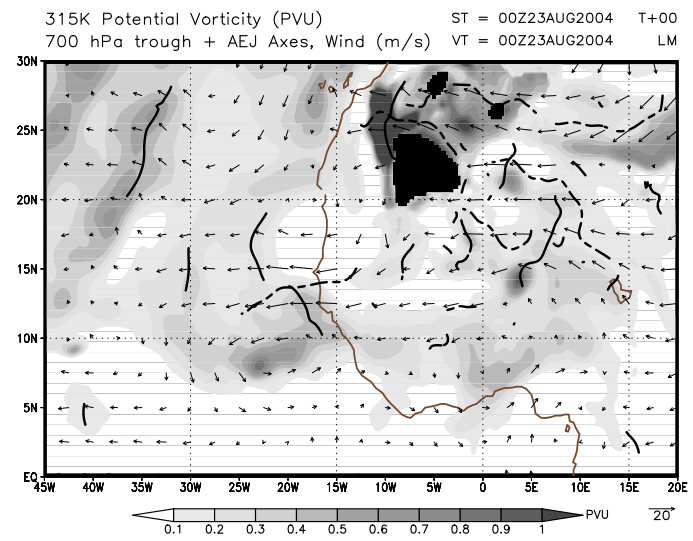

a) Analysis of 23 August 00 UTC

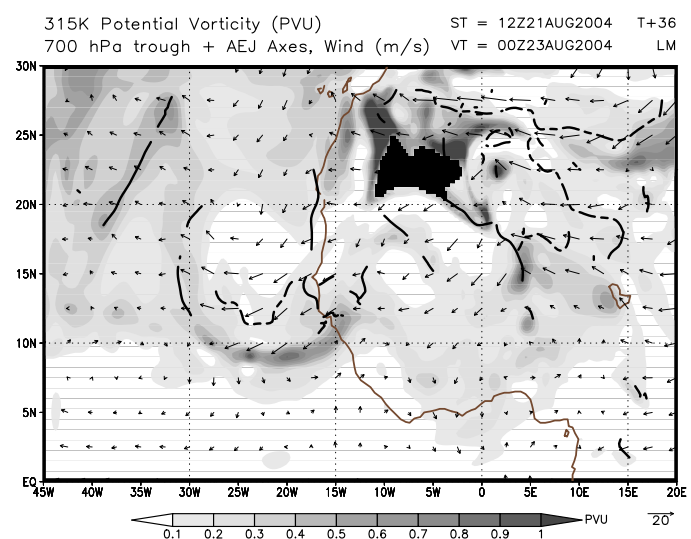

b) $36 \mathrm{~h}$ forecast from 21 August 12 UTC

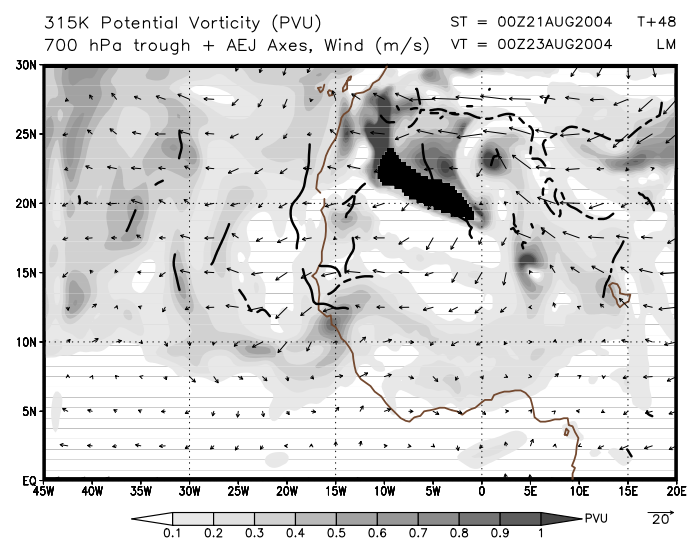

c) $48 \mathrm{~h}$ forecast from 21 August 00 UTC

Figure 4: PV on $315 \mathrm{~K}$ (shaded), wind vectors at $700 \mathrm{hPa}$ and objectively analysed jet axes (dashed) and trough lines (solid) for 00 UTC 23 August 2004. (a) Analysis, (b) $36 \mathrm{~h}$ forecast from 12 UTC 21 August and (c) $48 \mathrm{~h}$ forecast 00 UTC 21 August. The black shaded regions indicate where the $315 \mathrm{~K}$ surface is below the surface.

in fact associated with an incorrect representation of the synoptic scale flow. Given the horizontal resolution it is not surprising that the development of Frances is poorly represented. Indeed, the accuracy of the analysis must be called into question for this feature.

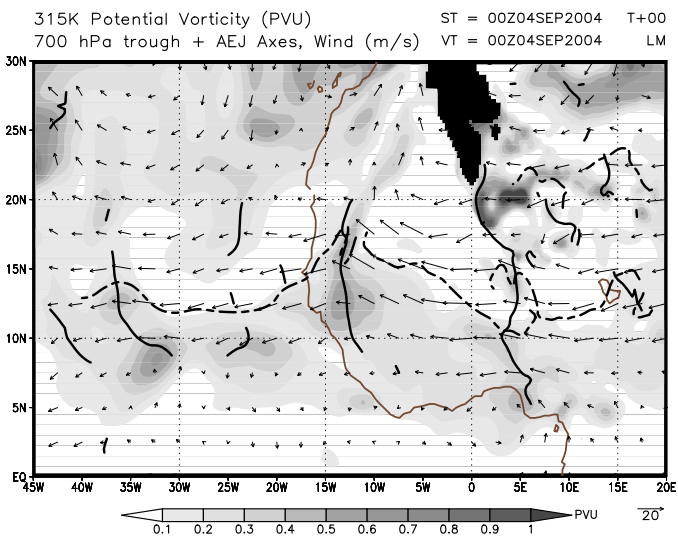

a) Analysis of 4 September 00 UTC

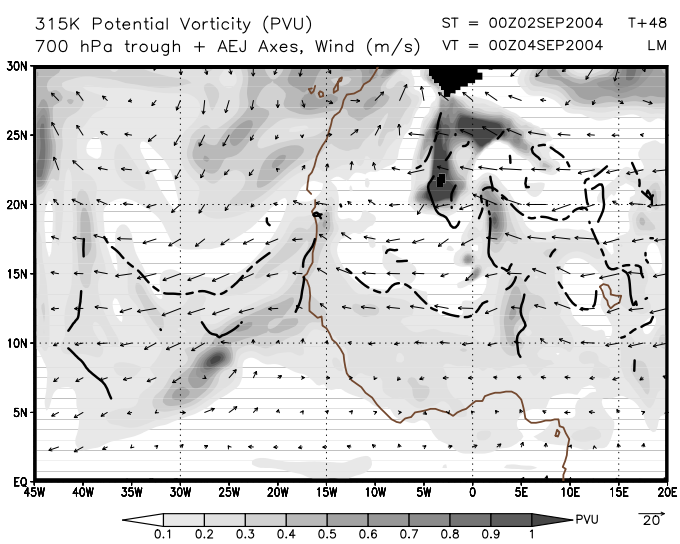

b) $48 \mathrm{~h}$ forecast from 2 September 00 UTC

Figure 5: As Fig. 4 for a) analysis and b) 48 h forecast valid on 00 UTC 4 September 2004.

The underestimate of the jet strength over Africa on 4 September 00 UTC appears to be associated with synoptic-scale developments also. Two pronounced trough axes are seen over West Africa, at $5^{\circ} \mathrm{E}$ and $12^{\circ} \mathrm{W}$. The easternmost trough extends from 5 to $23^{\circ} \mathrm{N}$ and there is a pronounced PV anomaly to the north of the jet axis (Fig. 5a). Between these troughs the jet axis has a southeast-northwest tilt with the strongest flow at about $10^{\circ} \mathrm{W}$ and $16^{\circ} \mathrm{N}$ between a pronounced region of anticyclonic vorticity to the north and cyclonic relative vorticity in the southern region of the western trough axis (Fig. 6a). In the forecasts, particularly at the longer lead times, the western trough is too weak and moves westwards too quickly. The northern and southern portions of the eastern trough separate, with the northern disturbance moving westwards more quickly (Fig. 5b). As a result, the large area of negative vorticity north of the jet axis between 0 and $10^{\circ} \mathrm{W}$ is weaker and smaller-scale and the analysed positive vorticity maximum near the West African coast south of the jet axis is not seen (Fig. 6b). Thus the jet axis does not exhibit the analysed southeast-northwest tilt and the zonal flow is much weaker. 


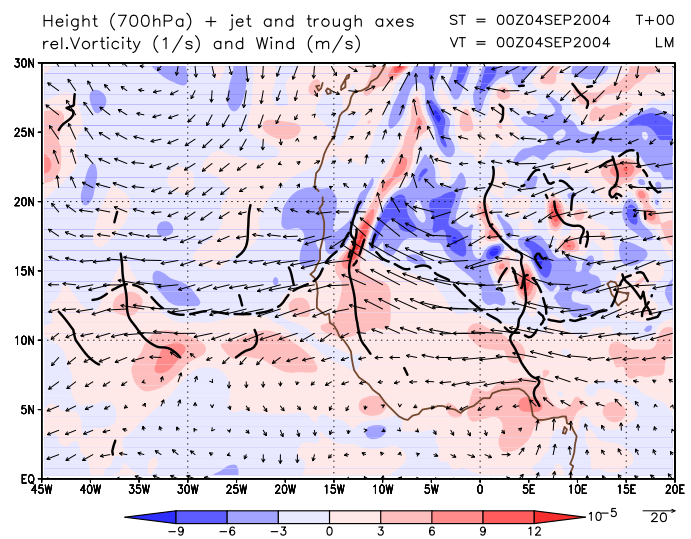

a) Analysis of 4 September 00 UTC

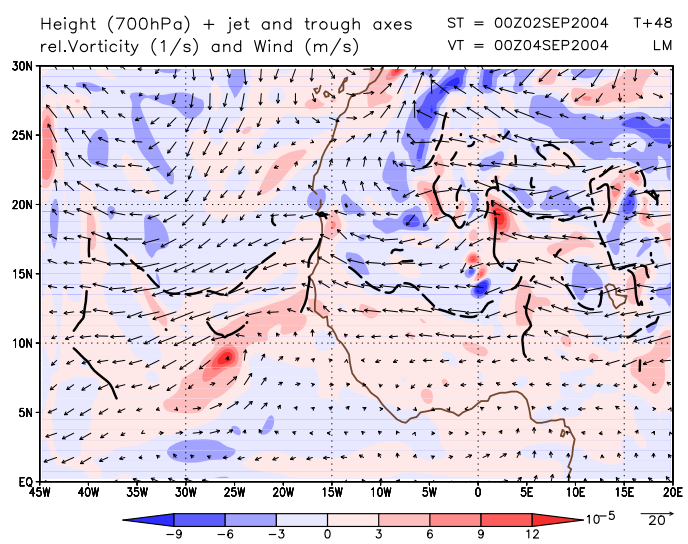

b) $48 \mathrm{~h}$ forecast from 2 September $00 \mathrm{UTC}$

Figure 6: Relative vorticity (shaded), wind vectors at $700 \mathrm{hPa}$ and objectively analysed jet axes (dashed) and trough lines (solid) for 00 UTC 4 September 2004. (a) Analysis and (b) $48 \mathrm{~h}$ forecast from 00 UTC 2 September.

The calculation shown in Fig. 3 was repeated for 600 $\mathrm{hPa}$ (not shown). The overall accuracy of the prediction of the jet maximum is comparable to the results presented for $700 \mathrm{hPa}$. For the cases discussed above the forecast errors at $600 \mathrm{hPa}$ were significantly smaller. This is consistent with the attribution of the error to synoptic scale features, or jet streaks, associated with AEWs, since these typically have maximum amplitude below $600 \mathrm{hPa}$.

\section{African Easterly Waves}

An overview of the AEW activity during our period is given using Hovmoeller-Plots for the latitude band $6^{\circ} \mathrm{N}$ to $16^{\circ} \mathrm{N}$ of the relative vorticity at $700 \mathrm{hPa}$ from the GME analysis and of the water vapour satellite imagery. The latitude band was chosen to capture the tracks of the AEWs that developed into Hurricanes Danielle, Frances and Ivan, and is largely south of the AEJ maximum so that we emphasise the disturbances to the south (FINK et al., 2004).

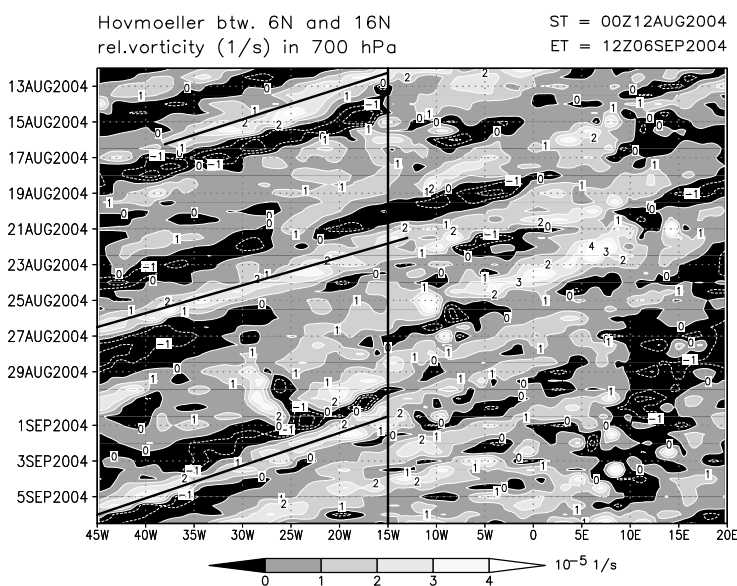

a)

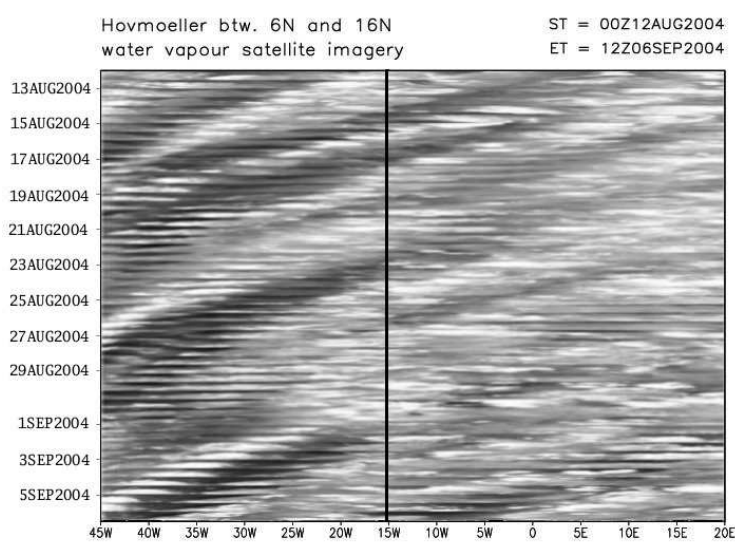

b)

Figure 7: Hovmoeller-Plots from 00 UTC 12 August to 12 UTC 6 September using 00 UTC and 12 UTC data. (a) $700 \mathrm{hPa}$ relative vorticity from GME analyses (b) water vapour satellite imagery (http://www.sat.dundee.ac.uk). Averaging carried out between $6^{\circ} \mathrm{N}$ and $16^{\circ} \mathrm{N}$. The vertical line in (a) shows the approximate location of the West African coast in the latitude band chosen. The three diagonal lines show the precursors of Hurricanes Danielle, Frances and Ivan.

The relative vorticity is shown in Fig. 7a, with positive values in white and negative values in black. A number of AEWs can be seen that develop over the continent, mainly between $5^{\circ} \mathrm{E}$ and $15^{\circ} \mathrm{E}$, and can be tracked over West Africa and the Atlantic. The structure over land is less clearly defined than that over water, both in relative vorticity and the satellite imagery. This may be an indication that the influence of the diurnal cycle on the convective systems, and thus on the relative vorticity and satellite imagery, is stronger over land than over water. Particularly noticeable are the 3 cloud bands (Fig. 7b) separated by approximately 10 days that highlight the progression of the AEWs from which the three hurricanes develop. The first AEW, the precursor of Hurricane Danielle, appears to decay on 16 August. This is because the hurricane moves northwards and exits the latitude band over which we average. 


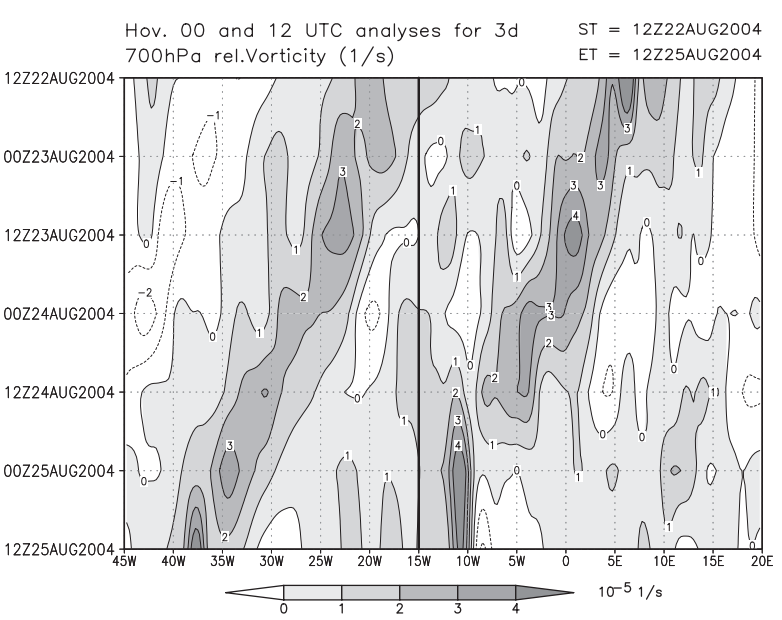

a) Analysis from 22 August 12 UTC

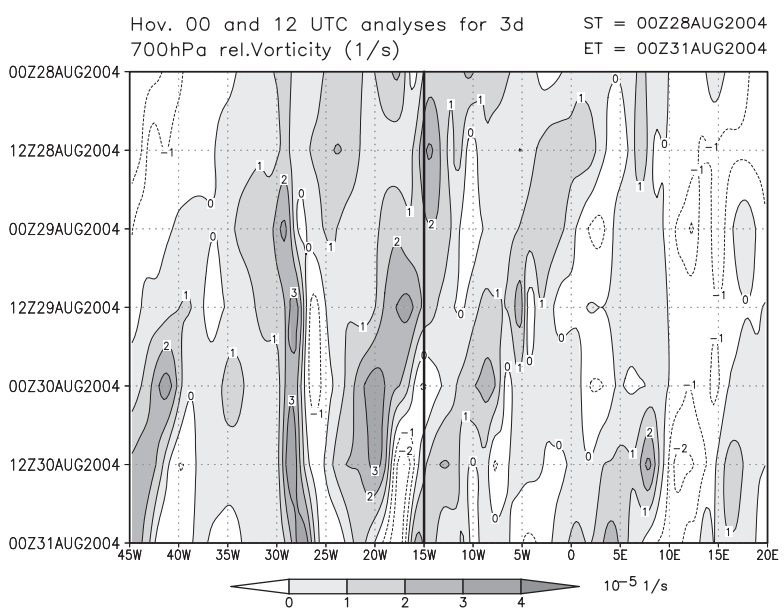

c) Analysis from 28 August 12 UTC

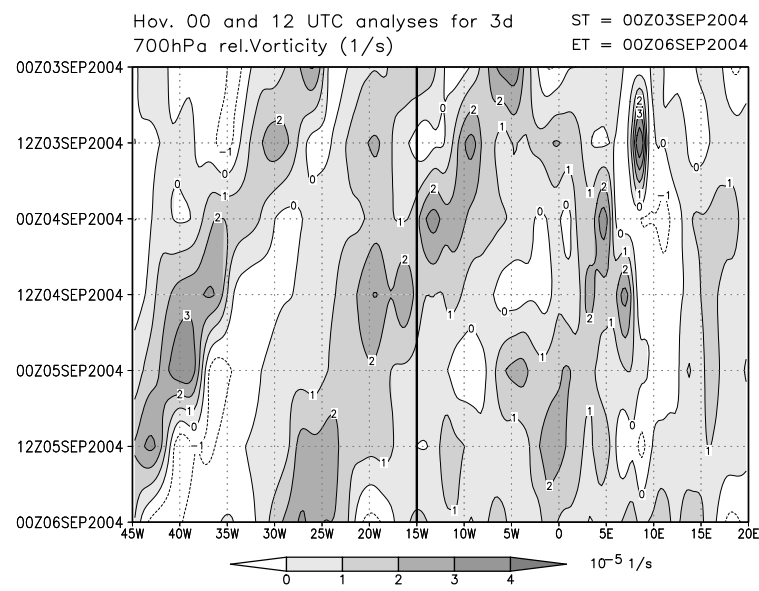

e) Analysis from 3 September 12 UTC
Hovmoeller 3d forecast $(6 \mathrm{~N}-16 \mathrm{~N}) \quad$ ST $=12 \mathrm{Z22AUG} 2004$ $700 \mathrm{hPa}$ rel.Vorticity $(1 / \mathrm{s})$ $E T=12 Z 25$ AUG2004

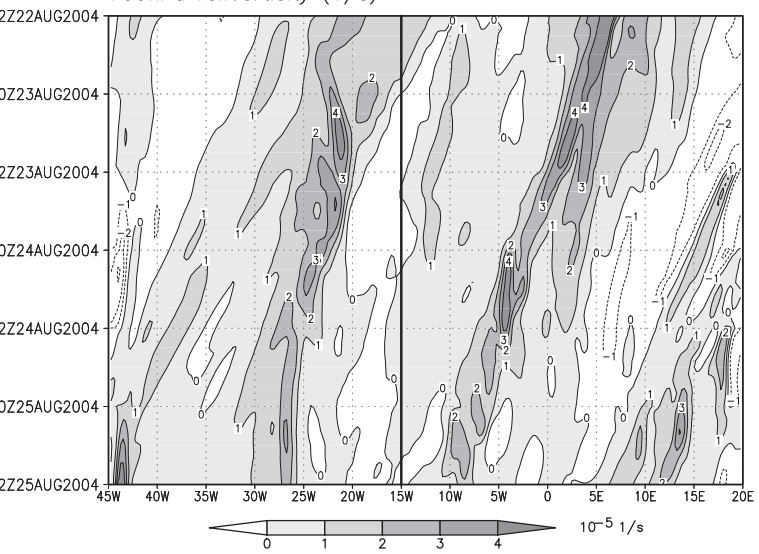

b) Forecast from 22 August 12 UTC

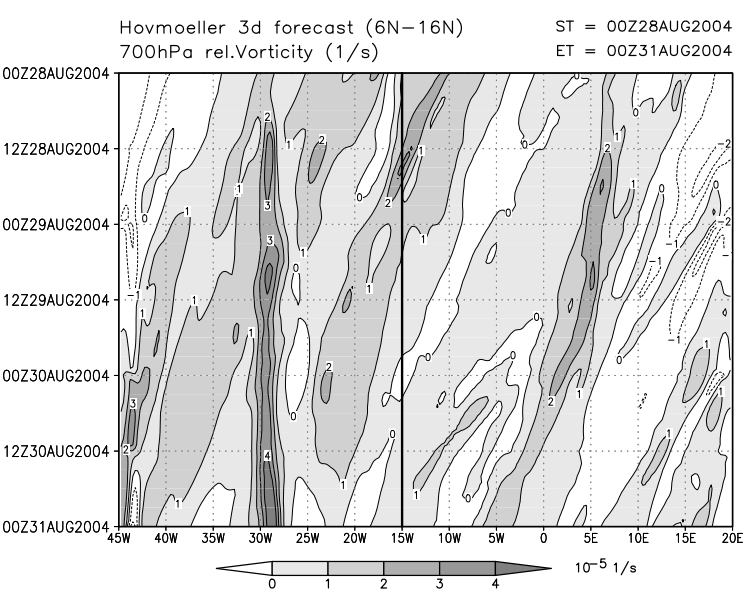

d) Forecast from 28 August 12 UTC

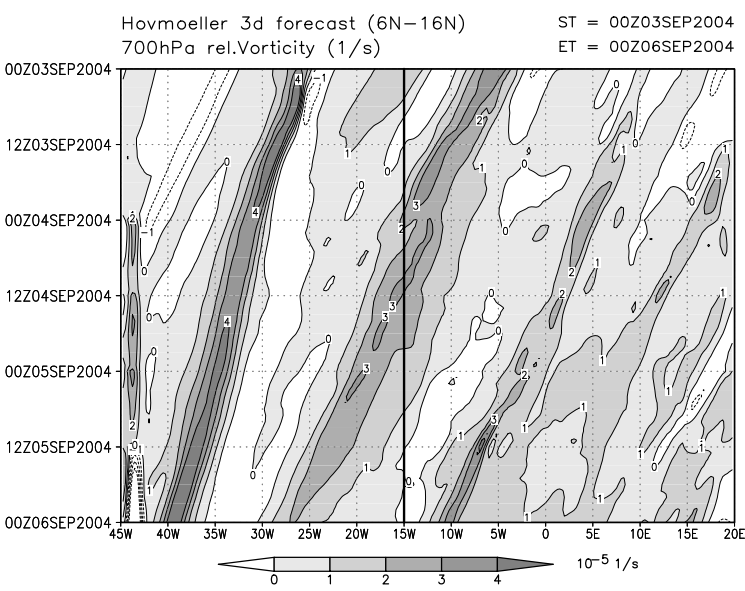

f) Forecast from 3 September 12 UTC

Figure 8: Hovmoeller-Plots averaged from 6 to $16^{\circ} \mathrm{N}$ of relative vorticity for $72 \mathrm{~h}$ periods. Analysis a) and forecast b) from 22 August 12 UTC. Analysis c) and forecast d) from 28 August 00 UTC. Analysis e) and forecast f) from 3 September 00 UTC.

In addition to the westward moving AEWs we see an apparently stationary system at $28^{\circ} \mathrm{W}$ between 29 August and 1 September. From horizontal cross sections (not shown) we see that this is indeed a stationary weather system and not a system that leaves the lat- itude band considered. A possible explanation for the stationarity of this system is that at this time Hurricane Ivan was developing further east and thus influencing the large-scale zonal flow. A further feature seen in Fig. 7 is the strong convection at the West African coast. Overall 


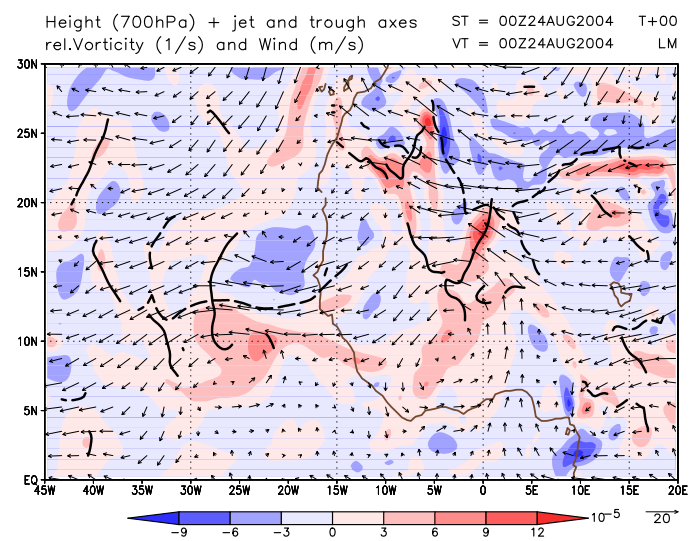

a) Analysis from 24 August 00 UTC

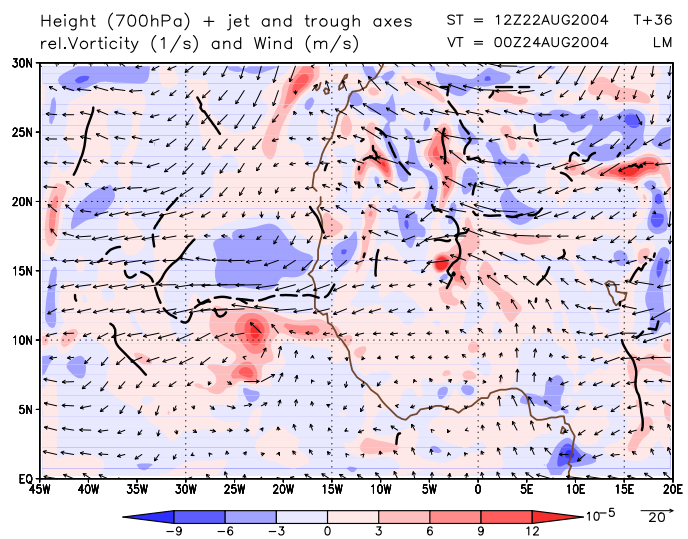

b) $36 \mathrm{~h}$ forecast of 22 august $12 \mathrm{UTC}$

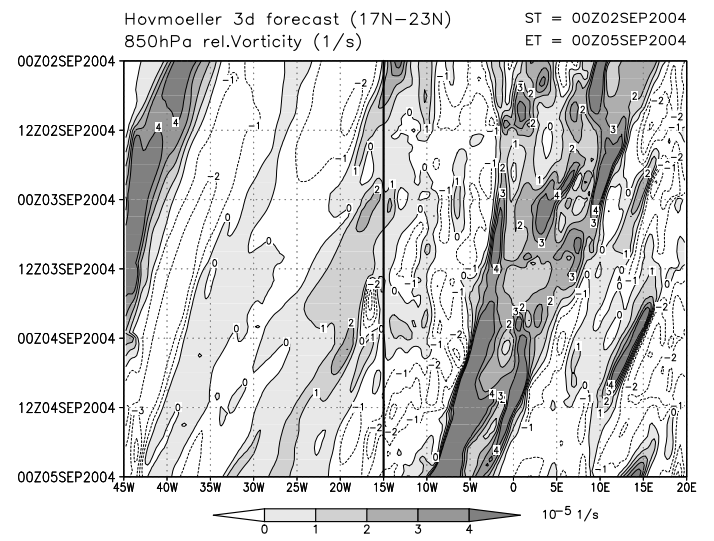

a) Forecast from 2 September 00 UTC

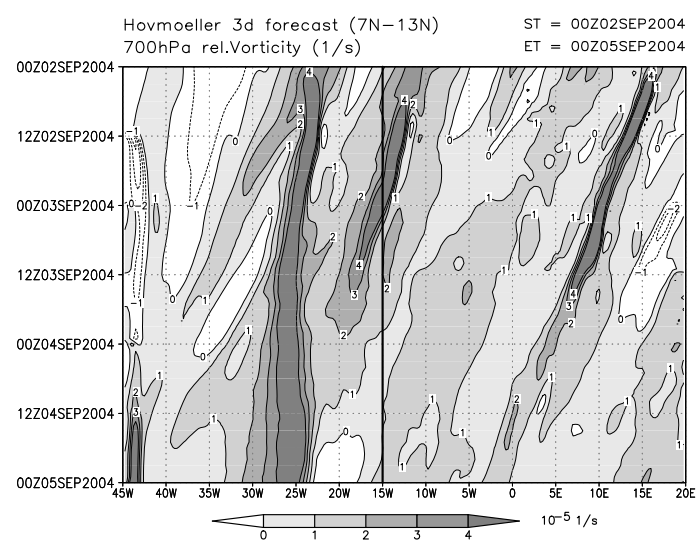

b) Forecast from 2 September 00 UTC
Figure 9: Relative vorticity, wind and jet and trough axes at $700 \mathrm{hPa}$ of a) the analysis and b) $36 \mathrm{~h}$ forecast for 24 August 00 UTC.

there is a good agreement with the dominant wave features in satellite imagery and the analysed relative vorticity field.

In order to investigate the model forecasts of AEWs we compare Hovmoeller plots for the $72 \mathrm{~h}$ forecasts with the corresponding analyses. As we do not have sufficient data to assess the quality of the analyses, we do not try to assess the quality of the forecasts in detail. However, the comparison indicates how small-scale structure develops in the higher resolution COSMO forecasts and to what extent this modifies the AEW propagation. Another issue is that the 12 hourly time resolution of the analyses may distort some features.

In the forecast from 22 August 12 UTC (Fig. 8a, b) we see the wave out of which Hurricane Frances subsequently developed crossing the West African coast and moving westwards. The westward boundary of the region of positive relative vorticity propagates at the same speed in analysis and forecast, but the vorticity maximum on the eastward side moves more slowly in the forecast as Frances strengthens (Fig. 9) and becomes quasi-stationary. The AEW over the continent in the
Figure 10: Hovmoeller-Plots averaged from a) 17 to $23^{\circ} \mathrm{N}$ and b) 7 to $13^{\circ} \mathrm{N}$ of $72 \mathrm{~h}$ forecast of relative vorticity for $72 \mathrm{~h}$ from 2 September 00 UTC.

Hovmoeller plots appears well represented in the forecast up to $48 \mathrm{~h}$. However, the southern portion of the AEW over the continent is not well represented in the forecast (Fig. 9). Although the region of positive vorticity appears stronger in the Hovmoeller plot (Fig. 8a, b), the cyclonic circulation at $5^{\circ} \mathrm{W}$ and $10^{\circ} \mathrm{N}$ is too weak. The Hovmoeller plot is sensitive to a small-scale and strong vorticity feature at $4^{\circ} \mathrm{W}$ and $15^{\circ} \mathrm{N}$ that probably develops in association with convection in the forecast. The stationary maximum in the analysis from $48 \mathrm{~h}$ belongs to a different system that develops ahead of the AEW trough at $9^{\circ} \mathrm{W}$ and $7^{\circ} \mathrm{N}$.

In the forecast from 28 August 00 UTC (Figs. 8c, d) a stationary band of high relative vorticity is seen in both forecast and analysis. It develops in both cases at about $28^{\circ} \mathrm{W}$ and can be recognised several hours earlier in the forecast than in the analysis. The high relative vorticity is associated with a convective system that developed out of a wavelike disturbance over the Atlantic. The system drifts northwards in the strong southerly monsoon flow. Reasonable agreement between analysis and forecast is seen also with the other features over the Atlantic. 
a)

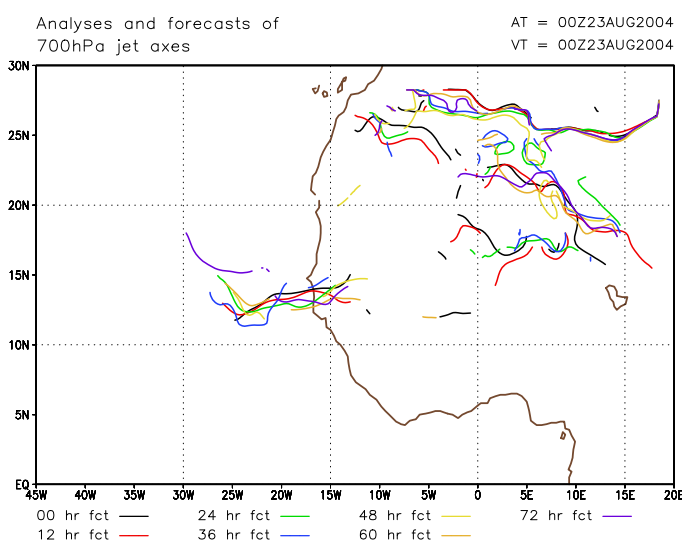

c)

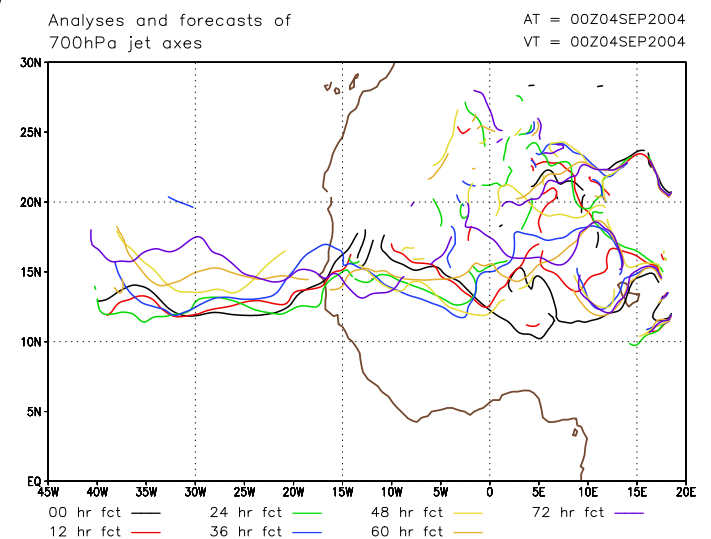

b)

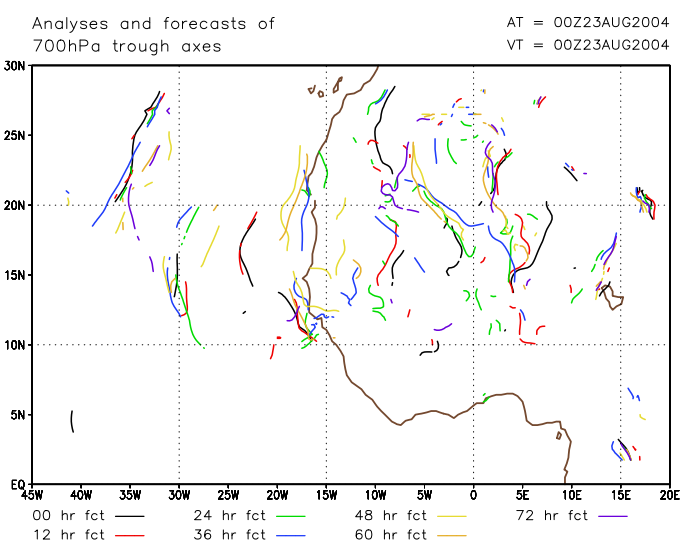

d)

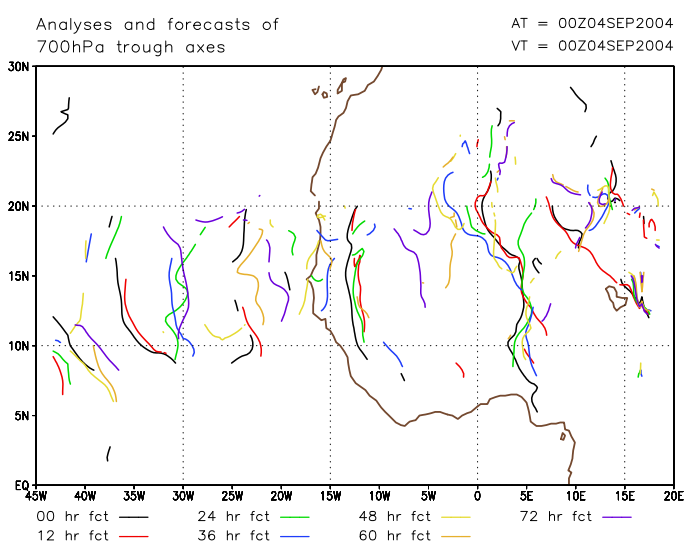

Figure 11: Analysis and forecasts of jet axes (left) and trough lines (right) for 23 August 00 UTC (top) and 4 September 00 UTC (bottom).

The AEWs over Africa are less well represented. However, the somewhat incoherent structures in the analysis lead us to raise the question as to whether the 12 hourly analyses reproduce the Hovmoeller plot adequately.

On a later date (forecast from 3 September 00 UTC) the agreement is good between forecast and analysis except in the easternmost portion of the domain (Fig. 8e and 8f). The forecast relative vorticity of the AEW that develops into Hurricane Ivan on 5 September (at $30^{\circ} \mathrm{W}$ at the start of the simulation) is higher than in the analysis and the motion of the system is slower in the forecast. With the data available it is not possible to ascertain whether the intensity forecast by the higher resolution COSMO is closer to the real intensity than the low resolution analysis. The propagation speed of the AEW that is initially over land and moves over water on 4 September 12 UTC is well represented. Although the westward motion of the developing Hurricanes Frances (Fig. 8b) and Ivan (Fig. 8f) is too slow in the forecast this does not appear to be a boundary problem, as there are many more examples of AEWs whose motion is correctly represented as they approach the western boundary.

Finally, we illustrate how Hovmoeller plots can identify differences between the northern and southern wave disturbances. Following FINK and REINER (2003) we average the $700 \mathrm{hPa}$ relative vorticity from $7-13^{\circ} \mathrm{N}$ and the $850 \mathrm{hPa}$ relative vorticity from $17-23^{\circ} \mathrm{N}$ for the case shown in Figure 5. The northern part of the wave (Fig. 10a) has a strong relative vorticity signature at $850 \mathrm{hPa}$ that extends between 5 to $15^{\circ} \mathrm{E}$ at the initial time. The southern wave (Fig. 10b) can be identified by a narrow band of positive relative vorticity and propagates more slowly westwards in the forecast than the northern wave.

A further graphical way of assessing the forecasts has been used by BERRY and THORNCROFT (personal communication). This involves plotting the objectively analysed jet axes and trough lines for a given verification time from a number of different forecast lead times. In Fig. 11 the jet and trough axes are plotted for the two times at which the average jet strength was underestimated. The analysis and forecasts for different leadtimes are plotted in different colours. For a perfect forecast the lines would coincide. On 23 August 00 UTC we see that although the forecast of the jet strength was poor, the forecast location of the jet axes was, with the exception of the $72 \mathrm{~h}$ forecast, rather good. Over Africa the jet is well north of its average position and the forecast agrees well with the analysis. On the other hand, the forecast 
of the trough axes over Africa are poor. After $24 \mathrm{~h}$ lead time they are either in the wrong position or not identified at all.

On 4 September the jet strength was underestimated, especially over Africa. Over the Atlantic (Fig. 11c) the jet location was forecast well until $36 \mathrm{~h}$ lead time. Subsequently the forecast jet axis was too far north, with the position error increasing with increasing lead time. Over Africa the location of the jet axis was poorly forecast, both in the region of the strongest jet $\left(0^{\circ} \mathrm{E}, 12^{\circ} \mathrm{N}\right)$ as well as further north. The forecast locations of AEW trough lines (Fig. 11d) are only accurate for the short term (up to $24 \mathrm{~h}$ ). The separation of the northern and southern portions of the trough located near $5^{\circ} \mathrm{E}$ can be seen. The first trough line to the west of the African coast moves too slowly in the forecasts. The same is observed for the trough line corresponding to Hurricane Ivan at $35^{\circ} \mathrm{W}$.

We have shown two examples here, chosen for times when we know there are problems with the forecasts. In general, the location of the jet axis is reasonably well forecast, but the forecasts of the trough axes are only satisfactory for a minority of cases. Due to the large variability in the jet location and strength during this period it is difficult to find a relationship between a particular synoptic situation and the forecast quality. There are indications, however, that the trough axes are better forecast, at least in the short term, for a stronger and more clearly defined jet.

\section{Conclusions}

In this study we have carried out a sequence of forecasts over a three week period in 2004 using COSMO. We have developed a diagnostic package for COSMO appropriate for West Africa and investigated different methods of evaluating the forecasts. We found that averaging the zonal flow along the objective jet axis gave a robust measure of the jet strength in the forecasts and highlighted errors in the synoptic scale flow. Comparing the mean zonal wind along the jet axes we found reasonably good agreement between analysis and forecasts up to $72 \mathrm{~h}$, except on a few particular days, on which the poor forecast is actually due to misrepresentation of synoptic-scale systems such as AEWs and developing tropical cyclones. We show that Hovmoeller plots can be used to assess the forecasts of AEWs. In some situations they must be interpreted with care, particularly when convection in the model produces small-scale but strong vorticity anomalies. In addition, the matching of the predicted with the analysed location of the jet axes is satisfactory for forecasts up to at least $36 \mathrm{~h}$. The quality of the forecasts of AEWs was rather more variable. In a number of cases either the strength or propagation of the AEWs was not well represented. Future work with
AMMA-SOP case studies will give us a better dataset which can be used to diagnose model performance and assess ways to improve the model configuration for West Africa.

\section{Acknowledgements}

This work is based to a large part on the Masters thesis of Nicole SANDER (LICHTENBERGER, 2005) and contributes to the AMMA-EU project. Based on a French initiative, AMMA was built by an international scientific group and is currently funded by a large number of agencies, especially from France, UK, US and Africa. It has been the beneficiary of a major financial contribution from the European Community's Sixth Framework Research Programme. Detailed information on scientific coordination and funding is available on the AMMA International web site (www.amma-international.org). The authors thank Gareth BERRY, Tim HEWSON and Chris THORNCROFT for their advice during the implementation of the objective analysis method. We also thank Cathérine MEISSNER for sharing her knowledge about COSMO. Water vapour satellite imagery was provided by NERC Satellite Receiving Station, Dundee University, Scotland (www.sat.dundee.ac.uk). We are grateful to the Deutscher Wetterdienst for providing the COSMO model and supporting its use. The comments of two anonymous reviewers helped us to improve this manuscript.

\section{References}

BERRY, G., C. THORNCROFT, 2005: Case study of an intense African Easterly Wave. - Mon. Wea. Rev. 133, 752-766.

Berry, G.J., C.D. Thorncroft, T. HEWSON, 2007: African Easterly Waves during 2004 - Analysis using objective techniques. - Mon. Wea. Rev. 135, 1251-1267.

BURPEE, R.W., 1972: The origin and structure of easterly waves in the lower troposphere of North Africa. - J. Atmos. Sci. 29, 77-90.

CARLSON, T.N., 1969a: Synoptic histories of three African disturbances that developed into Atlantic hurricanes. Mon. Wea. Rev. 97, 256-276.

_, 1969b: Some remarks on African disturbances and their progress over the tropical Atlantic. - Mon. Wea. Rev. 97, 716-726.

CHARNEY, J.G., M.E. STERn, 1962: On the stability of internal baroclinic jets in a rotating atmosphere. $-\underline{\mathrm{J}}$. Atmos. Sci. 19, 159-172.

COOK, K.H., 1999: Generation of the African easterly jet and its role in determining West African precipitation. - J. Climate 12, 1165-1184.

DICKINSON, M., J. MOLINARI, 2000: Climatology of sign reversals of the meridional potential vorticity gradient over Africa and Australia. - Mon. Wea. Rev. 128, 3890-3900.

DOMS, G., U. SCHÄTTLER, 2002: A description of the nonhydrostatic Regional Model LM. Part I: Dynamics and $\mathrm{Nu}-$ merics. Consortium for Small-Scale Modelling (Cosmo). www.cosmo-model.org. 
FINK, A.H., A. ReINER, 2003: Spatio-temporal Variability of the Relation between African Easterly Waves and West African Squall Lines in 1998 and 1999. - J. Geophys. Res. 108(D11), ACL 5-15-17, 4332, doi:10.1029/2002JD002816.

Fink, A. H., D.G. Vincent, P.M. Reiner, P. Speth, 2004: Mean state and wave disturbances during Phases I, II and III of GATE based on ERA-40. - Mon. Wea. Rev. 132, 1661-1683.

HALl, N.M.J., G.N. Kiladis, C.D. ThORnCROFT, 2006: Three-Dimensional Structure and Dynamics of African Easterly Waves. Part II: Dynamical Modes. - J. Atmos. Sci. 63, 2231-2245.

HSIEH J.-S., K.H. COOK, 2005: Generation of African easterly wave disturbances: Relationship to the African easterly jet. - Mon. Wea. Rev. 133, 1311-1327.

Hewson, T.D., 1998: Objective fronts. - Meteor. Appl. 5, 37-65.

LANDSEA, C.W., G.D. BELl, W.M. Gray, S.B. GoldenBERG, 1998: The extremly active 1995 Atlantic hurricane season: Environmental conditions and verification of seasonal forecasts. - Mon. Wea. Rev. 126, 1174-1193.

Lichtenberger, N., 2005: Modellierung von "African Easterly Waves" und deren Weiterentwicklung zu tropischen Wirbelstürmen mit dem Lokal-Modell des DWD. Www.imk.uni-karlsruhe.de/seite_3129.php.

Majewsin, D., D. Liermann, P. Prohl, B. Ritter, M. Buchhold, T. Hanisch, G. Paul, W. Wergen,
J. BAUmgARDNER, 2002: The Operational Global Icosahedral Hexagonal Gridpoint Model GME: Description and High-Resolution Tests. - Mon. Wea. Rev. 130, 319-338.

MEllor, G., T. YAMADA, 1974: A hierarchy of turbulent closure models for planetary boundary layers. - J. Atmos. Sci. 31, 1791-1806.

PARKER, D.J., C.D. Thorncroft, R.R. Burton AND A. Diongue-NiAng, 2005: Analysis of the African Easterly Jet, using aircraft observations from the JET2000 experiment. - Quart. J. Roy. Meteor. Soc. 131, 1461-1482.

ReED, R.J., D.C. Norquist, E.E. ReCKer, 1977: The structure and properties of African wave disturbances as observed during Phase III of GATE - Mon. Wea. Rev. 105, 317-333.

RIEHL, H., 1954: Tropical Meteorology. - McGraw-Hill, 392 pp.

RitTeR, B., J.F. GELEYN, 1992: A comprehensive radiation scheme for numerical weather prediction models with potential applications in climate simulations. - Mon. Wea. Rev. 120, 303-325.

TIEDTKE, M., 1989: A comprehensive mass flux scheme for cumulus-parameterization in largescale models. - Mon. Wea. Rev. 117, 1779-1799.

Thorncroft, C.D., M. BlaCkBurn, 1999: Maintenance of the African easterly jet. - Quart. J. Roy. Meteor. Soc. 125, 763-786.

ThORnCroft, C.D., B.J. Hoskins, 1994: An idealized study of African easterly waves. Part I: A linear view. Quart. J. Roy. Meteor. Soc. 120, 953-982. 